\title{
Genetic parameters for faecal egg count following natural nematode infections and correlation with productive traits in Polish Heath sheep
}

\author{
K.M. Charon ${ }^{1}$, B. Moskwa ${ }^{2}$, Z. Nowak ${ }^{1}$ and M. Szydlowski ${ }^{3}$ \\ 'Department of Genetics and Animal Breeding. Warsaw Agricultural University \\ Przejazd 4, 05-840 Brwinów, Poland \\ ' W. Stefariski Institute of Parasitology, Polish Academy of Sciences \\ Twarda 51/55, 00-818 Warsaw, Poland \\ ${ }^{3}$ Department of Genetics and Animal Breeding, August Cieszkowski Agricultural University \\ Wotyniska 33, 60-637 Poznań, Poland
}

(Received 5 April 2000; accepted 15 July 2000)

\begin{abstract}
Over a 4-year period, from May (1995) or June (1996-1998) to November, in a flock of Polish Heath shecp, faecal samples from 246 ewes, 9 rams and 429 lambs were examined for gastrointestinal nematode eggs by the McMaster method. Faecal cultures were run to identify the nematode species present. The prevalence of positive egg counts was, on average, 43 to $69 \%$ in ewes and 68 to $80 \%$ in lambs. Two nematode genera predominated: Haemonchus contortus and Trichostrongylus colubriformis. In the last three samplings in 1998 increased frequency of Ostertagia (Teludorsagia) circumcincta infections was noticed.

Animal model restricted maximum likelihood was used to estimate the heritability and repeatability for faecal nematode egg count (FEC) and corrclations with productive traits.

The obtained values of these parameters were $0.128( \pm .0 .011)$ and $0.068( \pm 0.005)$ for repeatability and heritability, respectively. A negative influence of faecal worm egg count on fleece weight of ewes and weight gain from birth to $3^{\text {rd }}$ month, from $3^{\text {rd }}$ month to $12^{\text {th }}$ month and during 12 months of lambs' life was observed. The estimated genetic correlations were: $-0.014( \pm 0.053),-0.197( \pm 0.046)$, $-0.204( \pm 0.073)$, and $-0.174( \pm 0.074)$, respectively.
\end{abstract}

KEY WORDS: sheep, nematode infection, genetic parameters, wool yield, weight gain

\section{INTRODUCTION}

Infections of ruminants with gastrointestinal nematodes can cause huge losses, in the case of sheep, up to $60 \%$ of all economic losses (Kloosterman et al., 1992). 
In New Zealand $60 \%$ of all sheep farms carry parasites resistant to anthelmintics and annual production losses are up to $\$ 270$ million (Morris ct al., 2000). In Poland the prevalence (percentage of infected animals) of gastrointestinal nematodes among sheep reaches $100 \%$ (Bouix ct al., 1998). Nematodes, such as Haemonchus contortus, causes a protein-losing gastroenteropathy, exacerbated by anacmia. Protein losses are due to anorexia, damaged digestive glands and the loss of protein through disrupted cell junctions (toxaemia ctc.). A result of gastrointestinal nematode infection among young animals is considerably lower body weight gain compared to uninfected animals (Coop et al., 1985). In extreme cases death can result.

One relatively cheap and simple method of reducing the effects of nematode infection is the selective breeding of nematode-resistant sheep (Baker, 1998; Bishop and Stear, 1999). This requires knowledge of the repeatability and heritability of faccal egg counts as well as genetic correlations with production traits. Many scientists have estimated the heritability $\left(\mathrm{h}^{2}\right)$ of cattle and sheep resistance to endoparasite infections, using nematode faecal egg counts as an indicator trait (Baker et al., 1988; Eady and Woolaston, 1995; Hanrahan and Crowley, 1999; Morris et al., 2000). However, these values may vary among breeds of sheep and different locations.

The aim of this study was to estimate the repeatability, heritability and correlation with wool yield of ewes and body weight gain of lambs of faecal nematode egg count in a flock of Polish Heath sheep.

\section{MATERIAL AND METHODS}

\section{Animals}

The study was carried out in 1995-1998 on prolific Polish Heath sheep (Romanov type) from a Warsaw Agricultural University experimental flock. Ewes (246 animals) were 2-5 years old, lambs (total number 429 ) were 3-6 months old. The number of recorded individuals is given in Table 1.

\section{Parasitological data}

Parasitological investigation of the basic flock of ewes was held every month, six times during the pasture season, from May to October. Each ycar 25 to 30 twoyear-old ewes replaced the culled animals. Lambs were examined annually (each ycar individuals from a new litter) four times from August to November. In the case of stock rams the degree of gastrointestinal nematode infections was checked in ycars 1997-1998 three times - in April, July and November. The gastrointestinal faecal egg count (FEC) of recorded animals was determined using McMaster's 
Prevalence of gastrointestinal nematode infections among Polish Heath sheep

\begin{tabular}{|c|c|c|c|c|c|c|c|c|c|c|c|c|c|c|c|c|c|c|}
\hline \multirow{3}{*}{$\begin{array}{l}\text { Month } \\
\text { of } \\
\text { sampling }\end{array}$} & \multicolumn{8}{|c|}{ Ewes } & \multicolumn{6}{|c|}{ Lambs } & \multicolumn{4}{|c|}{ Rams } \\
\hline & \multicolumn{2}{|c|}{1995} & \multicolumn{2}{|c|}{1996} & \multicolumn{2}{|c|}{1997} & \multicolumn{2}{|c|}{1998} & \multicolumn{2}{|c|}{1996} & \multicolumn{2}{|c|}{1997} & \multicolumn{2}{|c|}{1998} & \multicolumn{2}{|c|}{1997} & \multicolumn{2}{|c|}{1998} \\
\hline & $n$ & $\%$ & $\mathrm{n}$ & $\%$ & $\mathrm{n}$ & $\%$ & $\mathrm{n}$ & $\%$ & n & $\%$ & $n$ & $\%$ & $\mathrm{n}$ & $\%$ & $\mathrm{n}$ & $\%$ & $n$ & $\%$ \\
\hline IV & - & - & - & - & - & - & - & - & - & - & . & - & - & - & 9) & 11.0 & 9 & 0 \\
\hline V & - & - & 98 & 93.9 & 57 & 15.8 & 69 & 57.9 & - & - & - & - & . & - & - & - & - & - \\
\hline VI & 150 & 84.9 & 122 & 7.3 & 91 & 76.9 & 74 & 90.5 & . & . & . & - & . & - & - & . & . & . \\
\hline VII & 114 & 95.2 & 113 & 33.6 & 89 & 76.4 & 72 & 61.1 & - & - & - & - & - & - & 9) & 33.3 & 9 & 66.7 \\
\hline VIII & 140 & 67.4 & 108 & 66.7 & 94 & 86.2 & 67 & 35.8 & $\$ 14$ & 44.8 & 128 & 47.7 & 147 & 80.3 & - & - & - & - \\
\hline IX & 159 & 54.2 & 109 & 19.3 & 87 & 58.6 & 68 & 45.6 & 136 & 73.5 & 131 & 87.8 & 132 & 82.6 & - & - & - & - \\
\hline$X$ & 157 & 42.2 & 115 & 37.4 & 85 & 65.5 & 81 & 56.8 & 134 & 76.1 & 120 & 85.0 & 162 & 84.6 & - & - & . & - \\
\hline$X I$ & - & - & - & - & - & - & - & - & 123 & 79.5 & 117 & 79.5 & 161 & 74.5 & 9 & 33.3 & 9 & 66.7 \\
\hline $\mathrm{x}$ & 68 & 8 & 43 & 0 & & 32 & & 7.9 & 68. & & 75. & & 80 & & & 5.9 & & 4.5 \\
\hline
\end{tabular}

$\mathrm{n}$ - number of examined animals

$\%$ - percentage of infected animals

method (Bairden, 1991), in which each nematode egg counted represented 50 eggs per gram of faeces.

Because of the large number of eggs in facces, in May 1996 sheep were drenched with Systamex (Oxfendazole) at the dose rate recommended by the manufacturer. The drenching was repeated in December 1996. In the following years sheep were drenched at the end of grazing in November.

Faeces were cultured to identify parasite genera on the basis of morphological criteria characteristic of larvae (Anonymous, 1986). In each year, the faccal samples from the same sheep were used for nematode egg counts and larval cultures.

\section{Productive traits}

With the purpose of determining the influence of the nematode infection rate on production traits, correlations of FEC with wool yield of ewes and body weight gain of lambs in three periods were estimated for the periods from birth to the $3^{\text {rd }}$ month of life, $3^{\text {rd }}$ to $12^{\text {th }}$ month of life, and during the whole first year of life. In the studied flock, ewes were sheared twice a year, in the spring before lambing and during the autumn. In the study only the autumn shearing was taken into consideration, as the growth of wool after spring shearing occurred between the first and the last parasitological measurement.

\section{Statistical analysis}

The distribution of the FEC trait is considerably different from normal distribution (Morris ct al., 1997; Baker et al., 1999). Logarithmic transformation was used to increase the similarity to normal distribution: $\mathrm{LFEC}=\log (\mathrm{FEC}+1)$ (Bishop et 
al., 1996; Romjali et al., 1997). In the first stage of analysis, the effects of the type of birth (number of lambs in the litter), sex and year of birth were examined for each trait separately in a general linear model with the GLM procedure of the SAS package (1990). Statistically significant effects were included in the genetic analysis.

Genetic parameters were based on REML (Patterson and Thompson, 1971) estimates of (co)variance components. Variance components werc obtained on the basis of single trait animal model. The following linear model was used for FEC and wool yicld:

where:

$$
y=X b+Z_{a} a+Z_{p e} p e+e
$$

b is the vector of unknown fixed effects of sex and year for FEC and year for wool yield

$\mathbf{a}$ is the vector of unknown genetic additive random effects such that $\mathbf{a} \sim \mathrm{N}\left(\mathbf{0}, \mathbf{A} \sigma_{\mathrm{a}}{ }^{2}\right)$, with $\mathbf{A}$ and $\sigma_{\mathrm{a}}{ }^{2}$ being the additive genetic relationship matrix and additive genetic variance, respectively

pe is the vector of unknown random permanent environmental effects, pe $\sim \mathrm{N}\left(0, \mathrm{I} \sigma_{\mathrm{pc}}{ }^{2}\right)$, where $\sigma_{\mathrm{pc}}{ }^{2}$ is permanent environmental variance

e is vector of random residuals, e $\sim \mathrm{N}\left(\mathbf{0}, \mathbf{I} \delta_{c}{ }^{2}\right)$, where $\delta_{c}{ }^{2}$ is residual variance $\mathbf{X}$ and $\mathbf{Z}_{\mathrm{a}}$ and $\mathbf{Z}_{\mathrm{pe}}$ are known incidence matrices relating the corresponding effects to the observations.

In the analysis of lamb body weight gain, a reduced model was used with the vector of permanent random effects excluded and effects of type of birth, sex, and year considered as fixed. Estimates of heritability $\left(\mathrm{h}^{2}\right)$ and repeatability $(\mathrm{t})$ were obtained as $\mathrm{h}^{2}=\sigma_{\mathrm{a}}{ }^{2} /\left(\sigma_{\mathrm{a}}{ }^{2}+\sigma_{\mathrm{pc}}{ }^{2}+\sigma_{i}{ }^{2}\right)$ and $\mathrm{t}=\left(\sigma_{\mathrm{a}}{ }^{2}+\sigma_{\mathrm{p} i}{ }^{2}\right) /\left(\sigma_{\mathrm{a}}{ }^{2}+\sigma_{\mathrm{pc}}{ }^{2}+\sigma_{\mathrm{c}}{ }^{2}\right)$, respectively. Additive genetic covariances $\left(\sigma_{\mathrm{aij}}\right)$ and residual covariance $\left(\sigma_{\mathrm{cij}}\right)$ were estimated in bivariate analysis with individuals nested within traits. Additive genetic and residual covariance dispersion matrices were $\mathbf{A} \sigma_{\mathrm{ajj}}$ and $\mathbf{I} \sigma_{\mathrm{ejj}}$, respectively. Additive genetic correlations were calculated as $\mathrm{r}_{\mathrm{g}}=\sigma_{\mathrm{aij}} /\left(\sigma_{\mathrm{ai}} \sigma_{\mathrm{aj}}\right)$. For covariance estimation, mean values of repeated records were analysed instead of individual obscrvations and for FEC mean represented average value of transformed measures. The computations were performed using the REMLF90 package (Misztal, 1999).

\section{RESULTS AND DISCUSSION}

In each year of examination the prevalence of positive faecal egg counts (Table 1) varied. The smallest percentage of ewes in which nematode eggs were detected was noted in 1996, while the highest percentage occurred in 1995. For lambs the prevalence was least in 1996, and highest one in 1998. 
The mean nematode egg count was independent on the prevalence of positive faecal egg counts (Figure 1). In most studies Haemonchus contortus and Trichostrongylus colubriformis were inversely proportional, while the faecal egg count for all sheep groups (ewes, lambs and rams) significantly decreased with time.

In faecal cultures of sheep in 1996-1997 the following nematodes were found: H. contortus, Trichostrongylus spp., more recently - Ostertagia (Teladorsagia) spp., Cooperia spp., Nematodirus spp. and Chabertia spp. These results were confirmed by the parasitological section studies held in November 1997. The following parasite species were isolated from the abomasum and intestine: $H$. contortus, $N$. battus, O. circumcincta, T. colubriformis and T. vitrinus. Also other individuals belonging to previously mentioned genera were isolated, but they could not be classified to any specific species. In other studies, $H$. contortus and Tri-
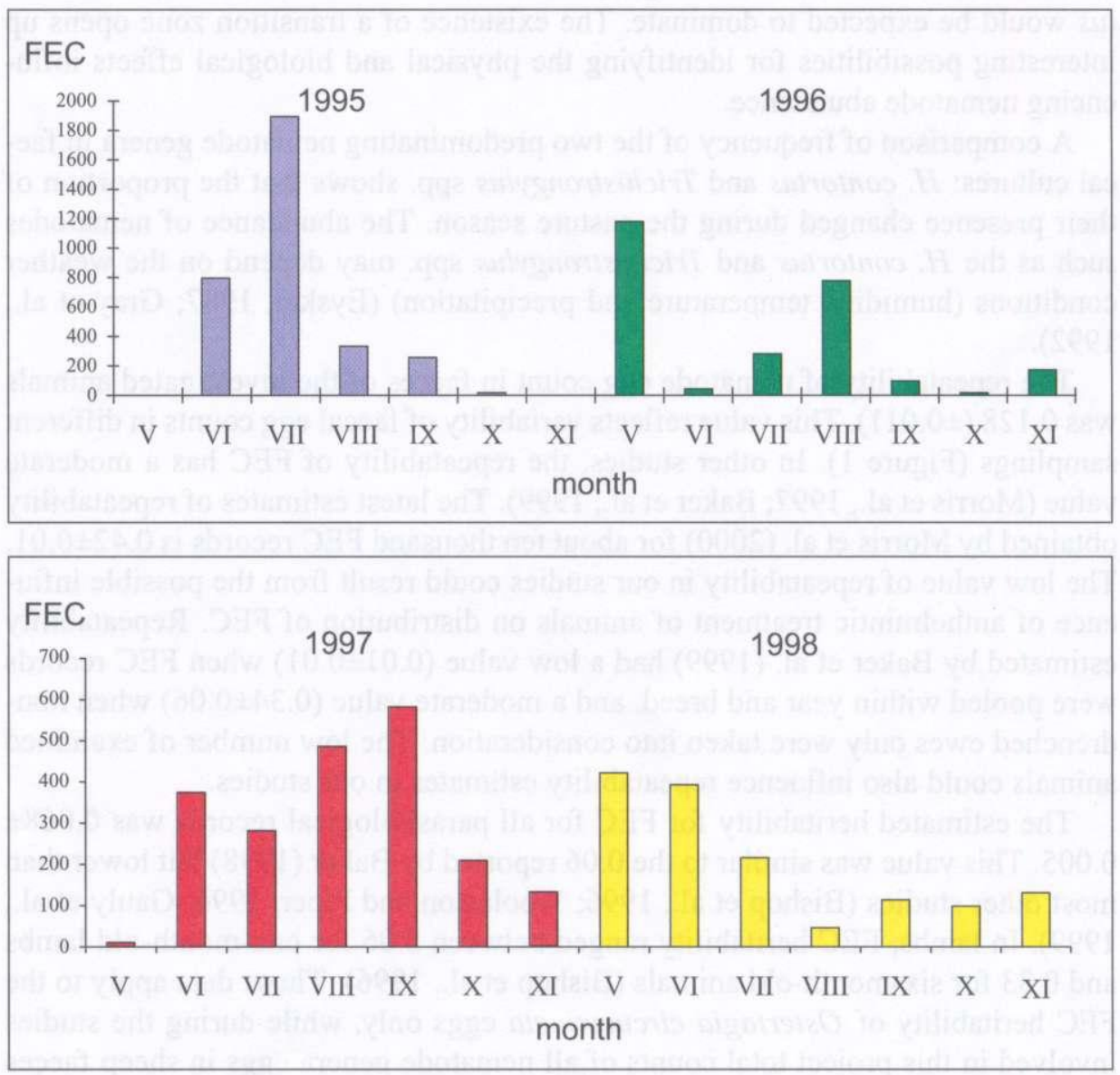

Figure 1. Faecal egg count in Polish Heath sheep 
chostrongylus spp. (mainly T. colubriformis) were also the dominant parasites among shecp from many European, Asian and American countries (Gray et al., 1992; Raadsma et al., 1997; Waller 1997). On the other hand, in more temperate climates, such as Northern Europe, or Southern Australia one of the most common nematodes is Ostertagia spp. (Stear et al., 1998). Sheep flocks from north Britain are infected mainly with $O$. circumcincta (Stear et al., 1995), but the most common nematode among flocks from southern parts of England is H. contortus (Mitchell, 1996).

In the examined sheep flock, Ostertagia circumcincta occurred with a various frequency, in 1996-1997 it was observed in 5-7\% of all sheep. In 1998 a considerable increase of the number of sheep infected with this nematode was recorded, with about $31 \%$ of faecal cultures containing it. The variable proportion of $O$. circumcincta may indicate that this area of Poland lies in a transition zone. Further North $O$. circumcincta might predominate while further South, H. contortus would be expected to dominate. The existence of a transition zone opens up interesting possibilities for identifying the physical and biological effects influencing nematode abundance.

A comparison of frequency of the two predominating nematode genera in faccal cultures: H. contortus and Trichistrongylus spp. shows that the proportion of their presence changed during the pasture season. The abundance of nematodes such as the $H$. contortus and Trichostrongylus spp. may depend on the weather conditions (humidity, temperature and precipitation) (Eysker, 1987; Gray et al., 1992).

The repeatability of nematode egg count in facces of the investigated animals was $0.128( \pm 0.011)$. This value reflects variability of faecal egg counts in different samplings (Figure 1). In other studies, the repeatability of FEC has a moderate value (Morris et al., 1997; Baker et al., 1999). The latest cstimates of repeatability obtained by Morris et al. (2000) for about ten thousand FEC records is $0.42 \pm 0.01$. The low value of repeatability in our studics could result from the possible influence of anthelmintic treatment of animals on distribution of FEC. Repeatability estimated by Baker et al. (1999) had a low value $(0.01 \pm 0.01)$ when FEC records were pooled within year and breed, and a moderate value $(0.34 \pm 0.06)$ when nondrenched ewes only were taken into consideration. The low number of examined animals could also influence repeatability estimates in our studies.

The estimated heritability for FEC for all parasitological records was $0.068 \pm$ 0.005 . This value was similar to the 0.06 reported by Baker (1998) but lower than most other studies (Bishop et al., 1996; Woolaston and Piper, 1996; Gauly et al., 1999). In lambs, FEC heritability ranged between 0.06 for one-month-old lambs and 0.33 for six-month-old animals (Bishop ct al., 1996). Those data apply to the FEC heritability of Ostertagia circumcincta eggs only, while during the studies involved in this project total counts of all nematode genera eggs in sheep faeces were taken under consideration. 
The relatively low heritability in our study may result from pooling samples from the beginning of the grazing season before immunity developed (Bishop et al., 1996) or samples that vary in the composition of nematode species. However, more research is needed to test these possibilities. In other studies the heritability of particular nematode species egg counts was higher, e.g. H. contortus: $0.34 \pm 0.10$ (Muggli, 1991, according to Kloosterman et al., 1992), 0.30 0.10 (Albers and Gray, 1989), $0.27 \pm 0.13$ (Piper, 1987), T. colubriformis: $0.41 \pm 0.19$ (Windon and Dineen, 1984).

Improving sheep resistance to gastrointestinal nematodes requires an understanding of costs and expected benefits. A major influence on expected benefits is the genetic basis of the selected trait: a single major gene or polygenes each of minor additive effect. Albers and Gray (1989) carried a simulated genetic progress; the only objective was to improve sheep resistance to gastrointestinal nematodes. They showed that with average heritability of this trait $(0.29)$, in the case of its polygenic character, a $30 \%$ improvement in the resistance to nematode infections is possible after about 12 years of screening. However, a $60 \%$ increase in resistance would be achicved after one year, by using rams homozygous for a dominant resistance gene.

Estimates of the correlation coefficient between FEC and production traits (wool yield of ewes and body weight gain of lambs) are shown in Table 2. All correlation coefficients, except genotypic correlation between FEC and wool yicld, estimated using the GLM procedure from the SAS package, are statistically significant $(\mathrm{P} \leq 0.05)$. Previous estimates made with the least square method gave higher correlation values. In these estimates, however, fewer parasitological measurements (1995-1997) were used (Charon et al., 1998).

Genetic correlations between FEC and liveweight are very variable, ranging from strongly negative (Bishop et al., 1996; Bouix ct al., 1998; Gauly et al., 1999) to moderately positive (Eady and Woolaston, 1995). Our results fall in the middle of the range. Differences among various studies may reflect different specics of parasite, breed of sheep or management conditions.

TABLE 2

Phenotypic $\left(r_{p}\right)$ and genetic $\left(r_{G}\right)$ correlations between FEC and production traits of Polish Heath sheep

\begin{tabular}{ccc}
\hline Traits & $\mathrm{r}_{\mathrm{p}}$ & $\mathrm{r}_{\mathrm{G}}$ \\
\hline FEC and body weight gain of lambs: & & \\
- from birth until $3^{\text {rd }}$ month & $-0.074 \pm 0.047$ & $-0.197 \pm 0.046$ \\
- from $3^{\text {rd }}$ until $12^{\text {th }}$ month & $-0.049 \pm 0.076$ & $-0.204 \pm 0.073$ \\
- from birth until $12^{\text {th }}$ month & $-0.079 \pm 0.075$ & $-0.174 \pm 0.074$ \\
FEC and wool yield of ewes & $0.017 \pm 0.058$ & $-0.014 \pm 0.053$ \\
\hline
\end{tabular}

FEC - faecal egg count 
The low positive phenotypic correlation between FEC and wool yield is consistent with the results of other studies (Morris et al., 1997, 2000). The decrease of wool yield in animals with low FEC can be a consequence of the immune system reaction to nematode infection. Sulphur-containing amino acids, such as cysteine, are required for both wool production and immune responses, so it is possible that a more intense immune response to nematode infection leads to reduced availability of these amino acids for fleece production (Miller et al., 1998). In contrast with other studies, the genetic correlations between FEC and wool yield were negative, though still low. This could reflect real differences between breeds or differing conditions (parasitological, management, etc.) among experiments.

\section{CONCLUSIONS}

A longitudinal parasitological investigation showed that flock of Polish Heath sheep had a high prevalence of gastrointestinal nematode infections. The mean percentage of positive faecal nematode egg counts in ewes ranged in separate years from about 43 to about $69 \%$, for lambs from about 68 to about $80 \%$. Haemonchus contortus, Trichostrongylus colubriformis were the main nematodes infecting sheep, but in the last three samplings in 1998 O. circumcincta dominated.

Although the repeatability and heritability of the FEC $(0.128$ and 0.068 , respectively) was low, it nevertheless suggested the possibility of selective breeding to improve sheep resistance to nematode infections.

\section{REFERENCES}

Albers G.A.A., Gray G.D., 1989. The genetics of parasite resistance in sheep. In: A.J. van der Zijpp, W. Sybesma (Editors). Improving Genetic Resistance in Farm Animals. Kluwer Academic Publishers, Dordrecht, pp. 153-159

Anonymous, 1986. Manual of Veterinary Parasitological Techniques. Ministry of Agriculture, Fisheries and Food. Her Majesty's Stationary Office, London

Bairden K.. 1991. Ruminant parasitic gastritis; some observations on epidemiology and control. Ph.D. Thesis, University of Glasgow (UK)

Baker R.L., 1998. Genetic resistance to endoparasites in sheep and goats. A review of genetic resistance to gastrointestinal nematode parasites in sheep and goats in the tropics and evidence for resistance in some sheep and goat breeds in sub-humid coastal Kenya. Anim. Genet. Resour. Inform. 24, 13-30

Baker R.L., Mwamachi D.M., Audho J.O., Aduda E.O., Thorpe W., 1999. Genetic resistance to gastro-intestinal nematode parasites in Red Maasai, Dorper and Red Maasai x Dorper ewes in the sub-humid tropics. Anim. Sci. 69, 335-344

Baker R.L., Watson T.G., Harvey T.G., 1988. Genetic variation in, selection for, resistance or tolerance to internal nematode parasites in sheep. Proceedings of the 3rd World Congress on Sheep and Beef Cattle. Paris, Vol. 1, pp. 637-639 
Bishop S.C., Bairden K., McKellar Q.A., Park M., Stear M.J., 1996. Genetic parameters for faecal egg count following mixed, natural, predominantly Ostertagia circuncincta infection and relationships with live weight in young lambs. Anim. Sci. 63, 423-428

Bishop S.C., Stear M.J., 1999. Selecting sheep for resistance to gastrointestinal nematode parasites. 50th Annual Meeting of EAAP, Zürich. Book of Abstracts 5, p. 260

Bouix J., Krupiński J., Rzepecki R., Nowosad B., Skrzyżala I, Roborzyński M., Fudalewicz-Niemczyk W., Skalska M., Malczewski A., Gruner L., 1998. Genetic resistance to gastrointestinal nematode parasites in Polish Long-Wool sheep. Int. J. Parasitol. 28, 1791-1804

Charon K.M., Moskwa B., Cabaj W., Olech W., 1998. Genetic resistance of sheep to natural infection with gastrointestinal nematode. World Congress on Genetics Applied to Livestock. Armidale (Australia), Vol. 27, pp. 347-350

Coop R.L., Graham R.B., Jackson F., Wright S.E., Angus K.W., 1985. Effect of experimental Ostertagia circumcincta infection on the performance of grazing lambs. Res. Vet. Sci. 38, 282-287

Eady S.J., Woolaston R.R., 1995. Genetic resistance to internal parasites in Merino sheep. 46th Annual Meeting EAAP, Prague. Book of Abstracts 1, p. 56

Eysker E., 1987. Regulation of Trichostrongylus vitrinus and T. colubriformis populations in naturally infected sheep in The Netherlands. Res. Vet. Sci. 42, 267-271

Gauly M., Mathiak H., Hoffmann K., Erhardt G., 1999. Genetic resistance to gastrointestinal nematode parasites in Rhonsheep. 50th Annual Meeting of EAAP, Zürich. Book of Abstracts 5, p. 262

Gray G.D., Barger I.A., Le Jambre L.F., Douch P.G.C., 1992. Parasitological and immunological responses of genetically resistant Merino sheep on pastures contaminated with parasitic nematodes. Int.J.Parasitol. 22, 417-425

Hanrahan J.P., Crowley B.A.. 1999. Evidence for breed differences in resistance to nematode parasitism. 50th Annual Meeting of EAAP, Zürich. Book of Abstracts 5, p. 261

Kloosterman A., Parmentier H.K., Ploeger H.W., 1992. Breeding cattle and sheep for resistance to gastrointestinal nematodes. Parasitol. Today 8. 330-335

Miller F.M., Blair H.T.. Reynolds G.W., Revell D.K., 1998. The role of cysteine in the increased parasite susceptibility of Romney sheep selected for hogget fleece-weight. Proceedings of N.Z. Soc. Anim. Prod. 58, 150-153

Mitchell L.. 1996. Clean grazing for parasite control. Farmer and Grower 52, 8-11

Misztal I., 1999. REMLF90 Manuaht ftp:/nce.ads.uga./edu/pub/ignacy/blupt90/. Accessed February 25

Morris C.A., Vlassoff A., Bisset S.A., Baker R.L., West C.J., Hurford A.P., 1997, Responses of Romney sheep to selection for resistance or susceptibility to nematode infection. Anim. Sci. 64 . 319-329

Morris C.A., Vlassoff A., Bisset S.A., Baker R.L., Watson T.G., West C.J., Wheeler M., 2000. Continued selection of Romney sheep for resistance or susceptibility to nematode infection estimates of direct and correlated responses. Anim. Sci. 70, 17-27

Patterson H.D., Thompson R., 1971. Recovery of interblock information when block sizes are unequal. Biometrika 58, 545-554

Piper L.R., 1987. Genetic variation in resistance to internal parasites. In: B.J. McGuirk (Editor), Merino Improvement Programs in Australia. Australian Wool Corporation, Melbourne (Australia), pp. 351-363

Raadsma H.W., Nicholas F.W., Egerton J.R., 1997. Breeding for resistance to multiple diseases in sheep: is it possible? Proceedings of the 4th International Congress for Sheep Veterinarians, Armidale (Australia), pp. 279-284

Romjali E., Pandey V.S., Gatenby R.M., Doloksaribu M., Sakul H., Wilson A., Verhulst A., 1997. Genetic resistance of different genotypes of sheep to natural infections with gastro-intestinal nematodes. Anim. Sci. 64, 97-104 
SAS, 1990. SAS Procedures Guide. Version 6. 4" Edition. SAS Institute. Inc., Cary. NC

Stear M.J., Bairden K., Bishop S.C., Gettinby G., McKellar Q.A., Park M., Strain S., Wallace D.S., 1998. The proceses influencing the distribution of parasitic nemalodes amongst naturally infected lambs. Parasitology 117, 165-171

Stear M.J., Bishop S.C.. Doligalska M., Duncan J.L., Holmes P., Irvine, J., McCricie L., McKellar Q.A., Sinski E.. Murray M., 1995. Regulation of egg production. worm burden, worm length and worm fecundity by host responses in sheep infected with Ostertagia circuncincta. Parasite Immunol. 17, 643-652

Waller P.J., 1997. Anthelmintic resistance. Vet. Parasitol. 37, 101-111

Windon R.G., Dineen J.K., 1984. Parasitological and immunological competence of lambs selected for high and low responsiveness to vaccination with irradiated Trichostrongy/us colubriformis larvae. In: J.K. Dineen, P.H. Outteridge (Editors). Immunogenetic Approaches to the Control of Endoparasites. CSIRO, Australia, pp.13-28

Woolaston R.R., Piper L.R., 1996. Selection of Merino sheep for resistance to Haenonchus contortus: genelic variation. Anim. Sci. 62, 451-460

\section{STRESZCZENIE}

Parametry genetyczne liczby jaj nicieni w kale owiec narażonych na naturalne infekcje $\mathrm{i}$ korelacje z cechami produkcyjnymi u owiec rasy wrzosówka

W ciagu 4 lat od maja (1995) lub czerwca (1996-1998) do listopada oznaczano liczbę jaj nicieni żołądkowo-jelitowych metodą McMastera w kale matek, tryków i jagniąt rasy wrzosówka. W celu identyfikacji gatunków nicieni występujących w kalc badanych zwierząt prowadzone były hodowle kultur kałowych. Średnio od 43 do $69 \%$ matek i od 68 do $80 \%$ jagniąt było zarażonych. Najczçściej występującymi pasożytami były: Haemonchus contortus i Trichostrongylus colubriformis. W trzech ostatnich badaniach w 1998 roku stwierdzono wzrost częstotliwości infekcji Ostertagia (Teladorsagia) circumcincta.

Oszacowana z zastosowaniem modelu osobniczego powtarzalność liczby jaj nicieni w kale (FEC) wynosi $0,128 \pm 0,011$, natomiast odziedziczalność $0,068 \pm 0,005$.

Stwierdzono tijemny wpływ infekcji pasożytniczych na masę wełny matek i przyrosty masy ciała jagniąt od urodzenia do 3. micsiąca, od 3. do 12. miesiąca oraz w ciągu 12. miesięcy życia. Oszacowane genetyczne korelacje wynoszą odpowiednio: - 0,0l4 (亡 0,053), - 0,197 ( $\pm 0,046)$, $-0.204( \pm 0,073), \mathrm{i}-0,174( \pm 0,074)$. 